\title{
Brand Attachment and Brand Loyalty: The Moderating Role of Nostalgic Connections
}

\author{
ZinebRhajbal $^{1}$, MustaphaKhouilid $^{2}$, Layla Saligane ${ }^{3}$, AbdellatifChakor $^{4}$ \\ ${ }^{1,2,3}$ Ph.D. students, Mohammed V University in Rabat, Morocco \\ ${ }^{4}$ Professor at the Faculty of law, Economic and Social Sciences, Souissi-Rabat, Mohammed V University of \\ Rabat,Morocco
}

\begin{abstract}
The development of the client portfolio has become at the heart of the business policies of companies. Managers are increasingly paying attention to their brand strategies and are focusing on strengthening the brandconsumer relationship. The objective of this paper is to study the relationship between the dimensions of brand attachment and the dimensions of fidelity while analysing the moderating role of nostalgic connections on this relationship. An empirical study was carried out on an accidental sample of 210 people. The results of structural modelling relate the positive and significant impact of addictive attachment on attitudinal and behavioural fidelity, while the attachment of friendship has a negative impact on both dimensions of loyalty. The moderating role of nostalgic connections has been rejected because of the inconsistency between the desire to recall a period of life or a person with the quality (happy or unhappy) of the period in question.
\end{abstract}

Keywords: Addictive attachment, attitudinal fidelity, behavioural fidelity, friendship attachment, nostalgic connections.

\section{INTRODUCTION}

The brand is becoming increasingly important in the management and strategy of companies. Its importance is not recent but is growing and is required in almost all sectors of activities. There are many examples to show the stakes of the brand. The creation of brand management departments, the increase in the number of brand studies carried out by companies to work on their brand identity, evaluating the perceived image of their brand, or building abrand personality.

These brand-centric studies also make it possible to legitimize decisive strategic decisions such as brand extension, brand modification and brand rejuvenation. Considered today as one of the most valuable assets of the company, the brand allows its development andhas become an asset with a real economic value; it creates value for the company, its partners and consumers.

Beyond its first function of identifying the marked product, or differentiation for a functional purpose to differentiate itself from the competition based only on the irresistible functional benefits, here the brand is considered as the only means allowing the Product that distinguishes it from other products that have the same intrinsic characteristics. In addition to the functional elements, the emergence of a symbolic differentiation allowed companies to have other strategic tools to face competition through values they create or adopt and communicate with its consumers in order to strengthen the brand-consumer relationship.This relationship, as we approach it, is the result of a metaphor of the interpersonal relationship applied to the brand-consumer relationship, allowing new concepts to be used in marketing such as trust, attachment, commitment that used to be specific to the disciplines of psychology and social psychology. These elements allow the creation of feelings of affiliation to the brand which derive from the abstract associations evoked by Keller in his model (Keller, 1993). The brand, through these associations, is able to represent or convey values of a deep cultural and personal nature, it may reflect a "life story" (Kleine et al., 1995). Researchers have decided to work particularly on the predisposition of consumers to develop an affective relationship that lasts in time, namely attachment (McQueen et al., 1993, Feldwick, 1996, Heilbrunn, 1996, Lacoeuilhe, 1997). This attachment to the brand is motivated by two antecedents that are the nostalgic connections and congruence of the individual-brand image (Michel and Vergne, 2004).

What we are trying to do in this article is to empirically validate the relationship between attachment treated according to its two components of dependence and friendship and loyalty with its two components, we ask ourselves the following questions: if the two dimensions of attachment do act in the same way on the two components of fidelity? We have been particularly interested in the moderating impact of nostalgic connections on the interactions between attachment and loyalty. 


\section{BRAND ATTACHMENT AND BRAND LOYALTY: A LITERATURE REVIEW}

First developed in the context of the work on relations between individuals (Maissonneuve, 1966, Bershcied and Walster, 1978), attachment has been transposed to the domain of possessions, especially objects. The first analyzes of values and the meaning given to possessions stemmed from the work of sociology. Baudrillard, Richins (1994) give the three logics of meaning associated with the object:

- A functional logic of the use value that looks at the functional characteristics;

- An economic logic of exchange value in relation to the cost of ownership (possession plays a role as a source of financial security and corresponds to an investment)

-A logic of sign value, here possession plays a dual role: the expression of personal values and the symbolization of social relations.

The materialism and the expressive function of consumption practices allow us to analyse the relation between person and object by considering two dimensions: temporal and identity.

The temporal dimension links the object with events in the consumer's life, the object constitutes a memory of the individual by allowing him to remember moments in his life related to events, places or people. (Divard and Robert-Demontrond, 1997). The object and its temporal dimension symbolizes a personal history, social relations or interpersonal connections (Belk, 1988; Ball and Tasaki, 1992; Richins, 1994) as a nostalgic stimulus, a source of attachment.

\subsection{Brand's attachment}

Old brands that have a "history" and have existed for generations while maintaining stability, can have a particular meaning for the consumer by reflecting "a life story", stability from one generation to another is one of the reasons behind the preference of certain brands. This stability makes it possible to forge links between members of the family of different generations (Davies 1979, Holbrook 1994, Holbrook and Schindler 1991). The instrumental or functional value of the brand is exceeded in order for the attachment to concern an affective variable by referring to nostalgic connections (Belaïd and Lacoeuilhe, 2005). The identity dimension is based on the symbolic dimension of the objects, here the consumer's attachment to the brands is motivated by emotions (Park and Srinivasan, 1994), and the individual attaches to a brand when it brings out cultural values and personal identities (Richins and Dawson, 1992). This can be translated into congruence between the concept of theself and the personality of the brand (Onkvisit and Shaw, 1987).

Attachment to the brand in this sense depends on its ability to retain the identity of the individual, brand preserving the past by establishing identity connections that maintain individual character. The brand then plays a very important role that allows the individual to remember a subject, a group of people to whom he is associated or to be. The brand can also meet the need for belonging.

To define the notion of attachment to the brand, the literature review allows us to consider the following definition: "A psychological variable that reflects a lasting and unalterable affective reaction (the separation is painful) and represent a psychological proximity with the brand". (Lacoeuille, 2000).Heilbronn(2001) returns to add precision that there are two types of attachment; a functional attachment and existential attachment.According to him, last type of attachment is the only type which expresses emotional ties and feelings drawn over time. Cristau (2003) defines attachment to the brand by integrating the notions of friendship and dependence: "a strong, lasting psychological, emotional relationship to a brand that results from a concomitant feeling" Friendship and dependence on the brand. "

To allow themeasurement for this concept, several authors have developed scales of measurement in order to operationalize the quality of the consumer-brand relationship.In 1994, Fournier, recognized for her pioneering work, has developed the Brand Relationship Quality (BRQ) to highlight the different ways of the consumer-brand relationship, based on a six-faceted construct; Intimacy, love / passion, connection to the self, interdependence, commitment and partnership quality of the brand. These facets can be grouped according to facets relating to cognitive beliefs: intimacy and quality of the partner; Facets linked to behavioural links and which are behavioural dependence and commitment and finally facets reflecting emotional and socio emotional attachment expressed by love / passion and nostalgic attachment. The work of (Fournier, 1994) on the individual-brand relationship makes it possible to establish a link with research that deals with the subject of attachment to objects and its sources (Czikszentmihalyi and Rochberg-Halton, 1981; Richins, 1994).

Attachment allows the development of a psychological proximity between the brand and its consumers, it is an evolutionary notion, and that is to say, it is likely to concern a period of the consumer's life. The attachment to a brand can then stop once that the specific period is over, the consumer then can detach himself from the brand once he judges that the brand values no longer match his own values. The intensity of the relationship that can bind a brand to its consumers depends on several factors that must be taken into account in order to understand the causal relationships between brand concepts such as attachment, commitment or loyalty. Among these elements, (Merunka, 2002) cites, among others, the type of products, the degree of involvement, the type of consumer as well as the culture and consumption patterns. The review of the literature allows us to 
identify two most studied determinants, which are, on one hand, nostalgic connections and on the other hand the congruence of individual-brand image. (Fournier, 1994; Lacoeuille, 2000; Michel and Vergne, 2004). The author (Gouteron, 2008) empirically confirmed that attachment has a role in building and maintaining a brandconsumer relationship, alongside with the trust and commitment (Gouteron and Louis, 2010). In the context of our study, we decided to limit our concentration on nostalgic determinants. In this perspective, the brand constantly tries to establish links with events specific to the individual's life in both time and space.

\subsection{Nostalgic Connections}

If nostalgia is seen as a widely exploited feeling in marketing practice it is recent that it has begun to interest researchers in marketing to better understand the symbolic meanings attached to the past as well as its power to sell and make customer loyal. The concept of nostalgia was more exploited in other areas such as medicine and psychology. Nostalgia no longer limits the concept to the simple "homesickness ", but begins to integrate the temporal dimension: "It is not places, but ages of childhood, not space, but time which gives its essential structure to the nostalgic turning "(Kant, 1798). The definition of nostalgia will appear in the middle of the 19th century in the French dictionary to no longer limit it to the homesickness, but will more broadly refer to "an evocation of the past imprinted with melancholy" (Larousse dictionary, 2000). Although the definitions of nostalgia differ somewhat according to the authors, the same idea always appears in filigrane according to which nostalgia, as emotion, or feeling, comprises two components: one positive and pleasant, andanother one, unpleasant and negative. This subtle balance between sadness and happiness, this sweet-bitter quality of emotion felt differentiates nostalgia from other states relating to the past, such as mourning. Recently the concept of nostalgia has made its appearance in the Marketing world. The interest shown by researchers in this tool is becoming increasingly important thanks to its translation of the unique and irreplaceable character of the brand. Its impersonal quality is also a great asset: Baker and Kennedy (1994) have asserted that personal experience is not a sine qua non condition for the consumer to feel nostalgic connections, so they have made the difference, and have distinguished three types of nostalgic associations.

- Real (personal) nostalgia: Personal nostalgia refers to personal memories that are specific to the individual and mainly lived during childhood. These are water battles, street soccer matches with neighbours, stories told by the grand moms;

- Simulated Nostalgia: Refers to common memories shared with the previous generation but that the individual has not actually lived;

- Collective nostalgia: It is a commonnostalgia to a whole generation. There are people, objects, events that have marked a whole generation and / or a whole culture (we can talk about the Hippie trend that marked the 60-70 generation, the Backstreet boys ...)

The existence of a relationship between nostalgia and attachment is explained by several studies (Heilbrunn, 2001; Belk 1990 and Holbrook 1991), demonstrating that the consumer appeals to his memories before attaching himself to the brand. Thus, the greater the nostalgic connections are, the greater the intensity of attachment to the brand is (Richins, 1994; Kleines et al 1995;Lacoeuilhe 2000a). The brand here can generate a nostalgic stimulus and allows the marked object to have a sentimental value that will be a source of attachment. Personal memories and special experiences are the foundation behind brands to pass their messages that tend to develop nostalgic consumer sentiment, old brands and those which have a past or a history that exceeds a generation especially mark the consumers. They can be used to ensure continuity and linkage between family members of different generations and become the support of an attachment relationship (Davies, 1979, Holbrook 1994 and Holbrook and Schindler 1991).

Attachment to a brand is thus explained by the fact that some of them act as depositaries in relation to events in the life of the individual (Lacoeuille, 2000).

\subsection{Brand Loyalty}

In the literature review, loyalty is a very studied notion, several studies have been interested in understanding this concept and converge towards two main approaches: behavioural approach (behaviourist) based on the study of purchasing behaviour and the attitudinal approach that treats the source of this buying behaviour.

\section{Behavioural approach:}

According to this theory, a consumer is faithful when he regularly buys the same brand (Sheth, 1968). In this case, the measurement of fidelity is rather simple because it can be measured by the actual purchasing behaviour: food rate, purchase sequence, probability of purchase, RFM measurement, etc.) It is a downstream approach that measures a result.

According to this approach, repeated purchases of the same brand or continuous shopping sequences are enough to qualify a customer as loyal; this practice relies on the intuitive notion that if the consumer buys a 
brand repeatedly then he is faithful to the brand. It is also the availability of behaviour data (customer databases, panels) that explains the use of this approach, except that simple repetitive buying behaviour does not allow talking about loyalty because the consumer can simply repurchase by simple habit or lack of choice or because of the risk and cost of the changing of brand. The distinction between different situations in consumer relations cannot be made by simple repetitive buying behaviour.

\section{The attitudinal approach:}

A loyal customer is a consumer who must demonstrate a repeated buying behaviour of a brand but also his behaviour is supported by favourable attitudes towards it. He must appreciate the brand he regularly buys and can even develop emotional ties with it.

BaldingeretRubinson, (1996) in their study of fidelity have confirmed the importance of attitude as a necessary condition of loyalty; they have grouped the faithful into three categories of consumers, for whom they measured the attitude, they found the following results:

"Very loyal": with more than 50\% chance of re-purchasing the same brand and among them $70 \%$ have a favourable attitude towards the brand;

"Moderate loyal ": between $10 \%$ and $50 \%$ chance of re-purchasing the same brand, $20 \%$ of the cases declare a favourable attitude towards the brand;

"Disloyal": between 0 and $9 \%$ chance to buy the same brand with only $1 \%$ of the cases declaring to have a favourable attitude towards it.

The necessity of this second condition was highlighted by the study of Day (1969), which carried out a study on the purchase forecasts realized from a combination of a behavioural and attitudinal measure of the loyalty which have been proved to be twice reliablethan those made using a pure stochastic model. Brands can play a role of stimuli that re-emerge old memories, their antiquity or their revivalist characteristics, so brands can encourage particular attitudes and behaviours, according to Kessous and Roux (2010) nostalgic brands benefit of a strong power of attachment which leads to loyalty.

\subsection{Research Hypothesis}

III. HYPOTHESIS AND METHODOLOGICAL APPROACH

In this paper, we start from the thesis that the dimensions of attachment positively affect the level of loyalty of consumers. This implies that they are more and more loyal when they feel a sense of attachment to the brand. In order to give a theoretical and empirical support of the existing relationship between the attachment and the fidelity of the clients while integrating the moderating impact of the nostalgic connections on this link, we based ourselves on the work of (Fournier, 1994;Lacoeuille, 2000;Michel and Vergne, 2004) for the integration of nostalgic connections as a moderator variable (Cristau, 2003) for the dimensions of attachment. Nostalgic connections seem - according to the literature - to have a positive moderating impact on the improvement of customer loyalty. Thus, we formulated the following hypothesis:

H1. Attachment of dependency has a positive impact on the brand loyalty;

- H1a. Attachment of dependency has a positive impact on behavioral loyalty.

- H.1b. Addictive attachment has a positive impact on attitudinal loyalty.

H2. The attachment of friendship has a positive impact on the brand loyalty;

- H2a. The attachment of friendship has a positive impact on behavioralloyalty

- H2b. The attachment of friendship has a positive impact on attitudinal loyalty

H3. The nostalgic connections have a positive moderating impact on the relationship between dependency attachment and fidelity

- H3a. Nostalgic connections have a positive moderating impact on the relationship between addictive attachment and behavioural loyalty.

- H3b. Nostalgic connections have a positive moderating impact on the relationship between addictive attachment and attitudinal loyalty.

H4. Nostalgic connections have a positive moderating impact on the relationship between friendship attachment and loyalty.

- H4a. Nostalgic connections have a positive moderating impact on the relationship between attachment of friendship and behavioral loyalty.

- H4b. Nostalgic connections have a positive moderating impact on the relationship between friendship attachment and attitudinal loyalty.

The confirmation or invalidation of these hypotheses was made through an empirical study whose methodology is presented in the following paragraphs. 


\subsection{Research methodology}

In this paper, we have opted for a survey in the data collection. The information is gleaned using an online questionnaire distributed to a heterogeneous sample. The first part deals with the components of attachment, the second part studies the notion of fidelity with its two dimensions: behavioral fidelity and attitudinal fidelity. The third part was devoted to the study of the variable nostalgic Connections. Finally, the fourth part deals with the socioprofessional and identification data of the respondents. We measured the different variables of the study using Likert 5-point differential semantic questions. We chose to do a sampling of convenience. After completing the survey, we collected 210 questionnaires that were the subject of our field study. The following table shows a factor analysis with Varimax rotation for the validation of the measurement items.

The fiveresearch axes are presented as following:

Table 1: Factor analysis with rotation Varimax

\begin{tabular}{|c|c|c|c|c|c|}
\hline Axes & Variables & $\begin{array}{l}\text { Relative } \\
\text { Contribution }\end{array}$ & $\begin{array}{l}\text { Total } \\
\text { variance } \\
\text { explained }\end{array}$ & Eigenvalues & $\begin{array}{l}\text { Cronbach's } \\
\text { alpha }\end{array}$ \\
\hline \multirow{3}{*}{ 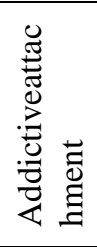 } & $\begin{array}{l}\text { I would be disappointed if I could not } \\
\text { find this brand when I need it }\end{array}$ & 0,910 & \multirow[t]{3}{*}{$78,745 \%$} & \multirow[t]{3}{*}{2,362} & \multirow[t]{3}{*}{0,863} \\
\hline & $\begin{array}{l}\text { I would be desperate if this brand were } \\
\text { removed from the market }\end{array}$ & 0,876 & & & \\
\hline & $\begin{array}{l}\text { It would struggle me to have to give up } \\
\text { buying this brand }\end{array}$ & 0,875 & & & \\
\hline \multirow{2}{*}{ 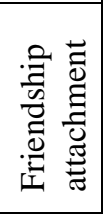 } & I feel pleasure using this brand & 0,942 & \multirow[t]{2}{*}{$88,733 \%$} & \multirow[t]{2}{*}{1,775} & \multirow[t]{2}{*}{0,873} \\
\hline & $\begin{array}{l}\text { The purchase of this brand gives me } \\
\text { much joy, pleasure }\end{array}$ & 0,942 & & & \\
\hline \multirow{3}{*}{ 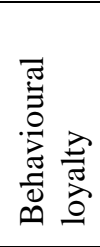 } & $\begin{array}{l}\text { I am loyal to a single brand in the } \\
\text { product category chosen }\end{array}$ & 0,928 & \multirow[t]{3}{*}{$84,032 \%$} & \multirow[t]{3}{*}{2,521} & \multirow[t]{3}{*}{0,905} \\
\hline & $\begin{array}{l}\text { I always buy the same brand of product } \\
\text { in the chosen category }\end{array}$ & 0,946 & & & \\
\hline & $\begin{array}{l}\text { Usually, I buy the same brand in the } \\
\text { chosen category }\end{array}$ & 0,874 & & & \\
\hline \multirow{2}{*}{ 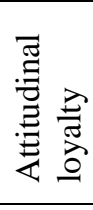 } & $\begin{array}{l}\text { For this product category, the first thing I } \\
\text { look at is the name of the brand }\end{array}$ & 0,768 & \multirow[t]{2}{*}{$59,056 \%$} & \multirow[t]{2}{*}{1,181} & \multirow[t]{2}{*}{0,306} \\
\hline & $\begin{array}{l}\text { The brand names available in the market } \\
\text { for this product category are very } \\
\text { similar. }\end{array}$ & 0,768 & & & \\
\hline \multirow{3}{*}{ 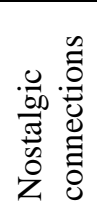 } & This brand is part of my personal story & 0,757 & \multirow[t]{3}{*}{$62,422 \%$} & \multirow[t]{3}{*}{1,873} & \multirow[t]{3}{*}{0,696} \\
\hline & $\begin{array}{l}\text { This brand reminds me of a particular or } \\
\text { important place of my past }\end{array}$ & 0,796 & & & \\
\hline & $\begin{array}{l}\text { This brand reminds me of my } \\
\text { relationship with a particular person. }\end{array}$ & 0,817 & & & \\
\hline
\end{tabular}

Source: Authors elaboration

\section{EMPIRICAL RESULTS}

Using the factor analysis of dependent and independent variables, we were able to identify the main components that will be used for the correlation and modelling test in structural equations. In this section we will try to see if there is a positive relation between the exogenous variables and the two endogenous variables. Before carrying out the analysis of the results of the structural equation modelling, we will first carry out a correlation analysis which will help us to detect the intensity and the direction of the relationship between the different axes of the research. To do this, we used the axes created with the Principal Component Analysis method.

\subsection{Correlation test}

Through empirical study, we have compared the two dimensions of attachment with the two dimensions of fidelity, while integrating the dimension of Nostalgic connections. Thus we assumed the existence of a positive relation between these variables except for the case of the interaction linking the variable 
nostalgic connections with the two dimensions of fidelity and whose moderating effect we want to measure. The relationship between the dependency attachment variable and the Behavioural fidelity variable is a positive, weak and significant relationship, when the dependency attachment increases, behavioural fidelity also increases, but not to the same degree $(\mathrm{Cor}=0.219$ and $\mathrm{p}$-value $=0.054)$. Also, the relationship between attachment dependence and attitudinal fidelity is not statistically significant (Cor $=0.131$ and $\mathrm{p}$-value $=0.255$ ), therefore there is no relationship between these two variables.

The relationship between friendship attachment and the two behavioural fidelity variables $($ Cor = 0.083 and $\mathrm{p}$-value $=0.471$ ) and attitudinal fidelity (Cor $=0.018$ and $\mathrm{p}$-value $=0.878$ ) is not statistically significant. Then, the variable nostalgic connections gave a negative and significant sign in its correlation with the Behavioural fidelity variable (Cor $=-0.249$ and $p$-value $=0.028$ ), and a significant result in its correlation with the attitudinal fidelity variable Cor $=-0.059$ and $p$-value $=0.610)$. This leads us to suppose the existence of a negative moderation relation of the nostalgic connections variable on the relation linking the dimensions of the attachment with the Behavioural fidelity.

Table 2: Correlations

\begin{tabular}{|l|l|l|l|l|l|}
\hline \multicolumn{2}{|c|}{} & $\begin{array}{l}\text { Friendship } \\
\text { Attachment }\end{array}$ & $\begin{array}{l}\text { Behavioural } \\
\text { Loyalty }\end{array}$ & $\begin{array}{l}\text { Attitudinal } \\
\text { Loyalty }\end{array}$ & $\begin{array}{l}\text { Nostalgic } \\
\text { Connections }\end{array}$ \\
\hline \multirow{2}{*}{$\begin{array}{l}\text { Dependence } \\
\text { attachment }\end{array}$} & $\begin{array}{l}\text { Pearson } \\
\text { Correlation }\end{array}$ & 0,629 & 0,219 & 0,131 & 0,157 \\
\cline { 2 - 6 } & Sig. (Bilateral) & 0,000 & 0,054 & 0,255 & 0,169 \\
\hline \multirow{2}{*}{$\begin{array}{l}\text { Friendship } \\
\text { Attachment }\end{array}$} & $\begin{array}{l}\text { Pearson } \\
\text { Correlation }\end{array}$ & 1 & $-0,083$ & 0,018 & 0,263 \\
\cline { 2 - 7 } & Sig. (Bilateral) & & 0,471 & 0,878 & 0,020 \\
\hline \multirow{2}{*}{$\begin{array}{l}\text { Behavioural } \\
\text { Loyalty }\end{array}$} & $\begin{array}{l}\text { Pearson } \\
\text { Correlation }\end{array}$ & & 1 & 0,538 & $-0,249$ \\
\cline { 2 - 7 } & Sig. (Bilateral) & & & 0,000 & 0,028 \\
\hline $\begin{array}{l}\text { Attitudinal } \\
\text { Loyalty }\end{array}$ & $\begin{array}{l}\text { Pearson } \\
\text { Correlation }\end{array}$ & & & 1 & $-0,059$ \\
\cline { 2 - 6 } & Sig. (Bilateral) & & & & 0,610 \\
\hline
\end{tabular}

Source: Authors elaboration

The analysis of the nature of the correlations binding the different variables cannot confirm or invalidate the hypotheses of the research. To do this, we analyse the results of the structural equation modelling to confirm the nature of the relationship that links all of the variables in our study.

\subsection{Structural equation analysis}

In this step, we tried to relate the study variables in a structural equation modelling to explain the behavioural fidelity and attitudinal fidelity variables. The items introduced in the model are those validated with the exploratory factor analysis (Varimax rotation) and with the Cronbach Alpha coefficient. We have rotated the model with the SPSS Amos software, and here are the results of the modelling.

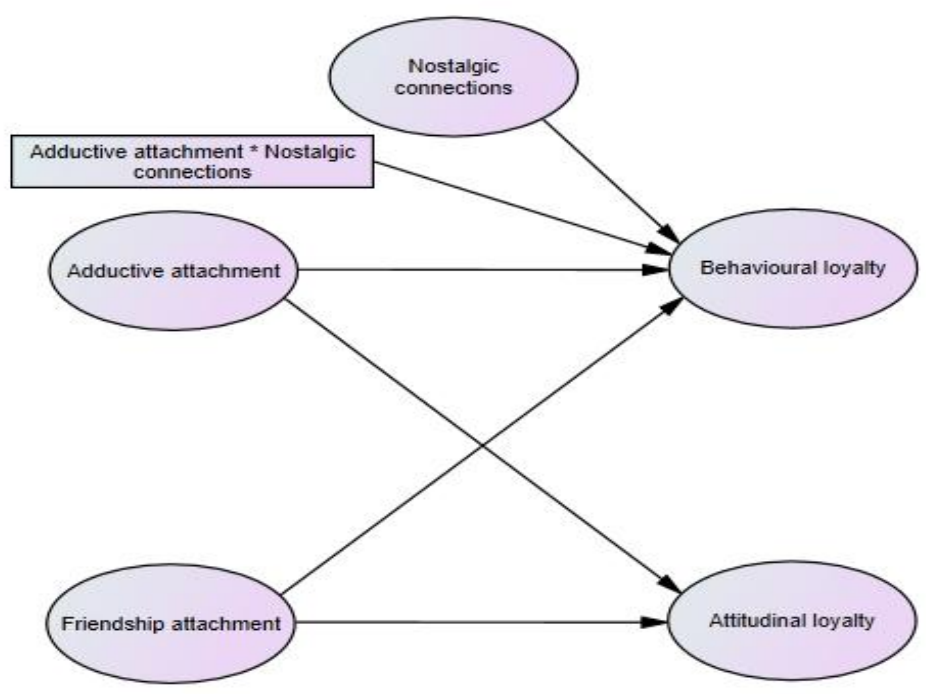

Fig 1: The causal model of research 
After validation of the measurement items, we opted for modelling in structural equations in order to validate the research hypotheses. We seek to show the existence of a significant causal relationship between the two exogenous dependency attachment and attachment of friendship variables, and the two endogenous behavioural and attitudinal fidelity variables. We also study the moderating impact of the variable nostalgic connections on the supposed - existing relations between the exogenous variables and the endogenous variables.

Since the test of the impact of a moderating variable requires the follow-up of several steps, we have turned several different models. The first model concerned the study of the relationships between the two exogenous dependency attachment and friendship attachment variables, and the two endogenous variables Behavioural fidelity and attitudinal fidelity, without integration of the moderator variable. In the second model, we have incorporated a causal relationship between the Connect variable and the two endogenous variables. This is a prerequisite before testing the moderator effect. Finally, in the third model we have integrated the indicator of the interaction term, it is calculated by the multiplication of the explanatory variable and the moderator variable, in our case: Attachment of dependence * Nostalgic connections. The results of the different models are presented in the following paragraph. In the causal model above we have not tested the moderating link of the nostalgic Connections variable on the relation linking the explanatory variables with the attitudinal fidelity variables since the direct causal link between the nostalgic connections and the attitudinal fidelity $\mathrm{n}$ Is not significant. The significance of this link is a prerequisite for testing moderator links. We also did not test the moderation on the effects of the Attachment of Friendship variable as it has negative coefficients contrary to the initial hypotheses. We calculated three analysis models, following the moderator test procedure. The first model integrates only the explanatory variables and the variables to be explained. The second model also includes the nostalgic connection variable as the explanatory variable. And finally, in the third model we have integrated the indicator of the interaction term in order to calculate the moderating effect for the significant causal links. The following table shows the results of the adjustment indicators calculated for each of the measurement models.

Table 3: Indices of adjustment quality of the measurement models

\begin{tabular}{|l|l|l|l|}
\hline Indices & $\begin{array}{l}\text { Values of the } \\
\text { independent model } \\
\text { (Without integration } \\
\text { of the nostalgic } \\
\text { connections } \\
\text { variable) }\end{array}$ & $\begin{array}{l}\text { Values of the } \\
\text { independent } \\
\text { model with } \\
\text { integration of the } \\
\text { connection } \\
\text { variable }\end{array}$ & $\begin{array}{l}\text { Values of the independent } \\
\text { model with integration of } \\
\text { the nostalgic connections } \\
\text { variable and the indicator } \\
\text { of the interaction term }\end{array}$ \\
\hline Chi-square (p) & $87,943(0,000)$ & $119,756(0,000)$ & $323,955(0,000)$ \\
\hline Degree of freedom (p) & 31 & 59 & 72 \\
\hline Normed Chi-square & 2,837 & 2,03 & 4,499 \\
\hline Standardised RMR & 0,48 & 0,39 & 14,919 \\
\hline GFI & 0,835 & 0,825 & 0,715 \\
\hline AGFI & 0,706 & 0,73 & 0,584 \\
\hline RMSEA (p) & $0,154(0,000)$ & $0,116(0,000)$ & $0,213(0,000)$ \\
\hline NFI & 0,806 & 0,775 & 0,561 \\
\hline CFI & 0,86 & 0,866 & 0,61 \\
\hline CAIC (Saturated model) & $216,505(294,619)$ & $291,171(487,461)$ & $500,727(562,454)$ \\
\hline
\end{tabular}

Source: Authors elaboration

The table above indicates that the independent model without integration of the variables Nostalgic connections presents a good fit for the results of the different indices calculated to measure the quality of the causal model, namely the indices: Chi-deux / ddl $=2.837$, RMR $=0.48$, GFI $=0.835$, AGFI $=0.706$, NFI $=$ 0.806 and $\mathrm{CFl}=0.86$. The majority of these indices are at a level deemed acceptable by the standard. The absolute and comparative quality indices of fit are satisfactory and show a good quality of prediction of the calculated model. The RMR index also asserts the increase in the quality of adjustment of the causal model. The integration of the Nostalgic Connections variable in the causal research model led to a decrease in the majority of indexes of adjustment quality. On the other hand, we have seen an improvement in the AGFI, CFI and RMSEA indicators. The decline in quality is not very significant and the model created partly meets the quality requirements of the standard. The shift to the third model, including the indicator of the interaction term, has led to the deterioration of the set of adjustment indicators that have become significantly below the norm. Only the standard Chi-square coefficient showed a significant increase. The analysis of these results allows us to conclude that we must reject the hypothesis that nostalgic connections have a moderating impact on the effects of attachment dimensions on behavioural and attitudinal fidelity. Confirmation of the other assumptions will be made by analysing the coefficients estimation table. We investigate the estimation of the parameters of the causal models in order to study the significance of the links and to validate the hypotheses. The following table presents the results of the Student's T test and the significance. 
Table 4: Results of the causal links and their significations

\begin{tabular}{|c|c|c|c|c|c|c|c|c|c|}
\hline \multirow{2}{*}{ Causal link } & \multicolumn{3}{|c|}{$\begin{array}{l}\text { Values of the } \\
\text { independent model } \\
\text { (Without integration of } \\
\text { the nostalgic } \\
\text { connections variable) }\end{array}$} & \multicolumn{3}{|c|}{$\begin{array}{l}\text { Values of the } \\
\text { independent model } \\
\text { with integration of the } \\
\text { connection variable }\end{array}$} & \multicolumn{3}{|c|}{$\begin{array}{l}\text { Values of the } \\
\text { independent model } \\
\text { with integration of the } \\
\text { nostalgic connections } \\
\text { variable and the } \\
\text { indicator of the } \\
\text { interaction term }\end{array}$} \\
\hline & 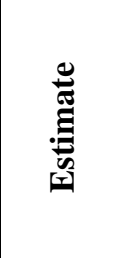 & 苛 & 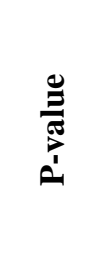 & 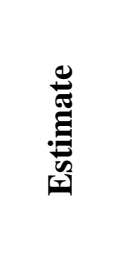 & 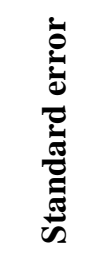 & 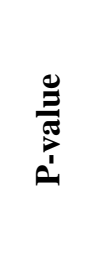 & 莺 & 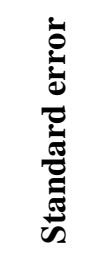 & 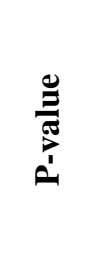 \\
\hline $\begin{array}{l}\text { Adductive attachment } \\
\rightarrow \text { Behavioural loyalty }\end{array}$ & 0,682 & 4,274 & 0,000 & 0,67 & 4,339 & 0,000 & 1,251 & 7,027 & 0,000 \\
\hline $\begin{array}{l}\text { Adductive attachment } \\
\rightarrow \text { Attitudinal loyalty }\end{array}$ & 0,359 & 2,24 & 0,025 & 0,352 & 2,208 & 0,027 & 0,418 & 2,593 & 0,01 \\
\hline $\begin{array}{c}\text { Friendship } \\
\text { attachment } \rightarrow \text { Behavioural } \\
\text { loyalty }\end{array}$ & $-0,52$ & $-3,787$ & 0,000 & $-0,422$ & $-3,261$ & 0,001 & $-0,423$ & $-3,378$ & 0,000 \\
\hline $\begin{array}{l}\text { Friendship attachment } \\
\rightarrow \text { Attitudinal loyalty }\end{array}$ & $-0,22$ & $-1,691$ & 0,091 & $-0,177$ & $-1,419$ & 0,156 & $-0,237$ & $-1,852$ & 0,064 \\
\hline $\begin{array}{l}\text { Nostalgic connections } \\
\rightarrow \text { Behavioural loyalty }\end{array}$ & -- & -- & -- & $-0,559$ & $-2,463$ & 0,014 & 0,276 & 1,334 & 0,182 \\
\hline $\begin{array}{l}\text { Nostalgic connections } \\
\rightarrow \text { Attitudinal loyalty }\end{array}$ & -- & -- & -- & $-0,217$ & $-1,085$ & 0,278 & -- & -- & -- \\
\hline $\begin{array}{l}\text { Adductive attachment } * \\
\text { Nostalgic connections } \\
\rightarrow \text { Behavioural loyalty }\end{array}$ & -- & -- & -- & -- & -- & -- & $-0,015$ & $-6,299$ & 0,000 \\
\hline
\end{tabular}

Source: Authors elaboration

The results of the first model agree that there is indeed a causal relationship between the dependency attachment variable and the two dimensions of fidelity, namely, behavioural fidelity and attitudinal fidelity. The estimation of the parameters gives a positive and significant sign at the 5\% threshold. On the other hand, the estimation of the parameters of the impact of the Attachment of friendship variable on the dimensions of fidelity gives negative and significant signs at the $10 \%$ threshold for the impact on the variable attitudinal fidelity. According to these results, addictive attachment has a positive and significant impact on loyalty, while the attachment of friendship has an unimportant negative impact on loyalty.

In the second model, the integration of the Nostalgic Connections variable disrupted the calculated error for parameter estimation. The causal link between the Attachment of Friendship variable and the Attitudinal Fidelity variable has become insignificant. Thus, the causal link between the variable Nostalgic Connections and the Attitudinal Fidelity variable is now insignificant. As a result, we can only analyse the impact of the moderator effect on linkages with the Behavioural fidelity variable. However, the integration of the interaction term in the third model to calculate the effect of moderation gave an unsatisfactory result. The link between nostalgic connections and Behavioural fidelity has become insignificant. The significance of the link is a necessary condition for confirming the moderator effect. Thus, the integration of the interaction term has led to a considerable decline in the indicators of the quality of adjustment, which leads us to reject the hypothesis of moderation of the nostalgic Connections on fidelity.

The empirical results show that only addictive attachment leads to an improvement in behavioural fidelity and attitudinal fidelity without this relationship being moderated by consumers' nostalgic connections. In addition, there are other factors affecting loyalty, which we have not been able to take into consideration in this paper, which is one of the limitations of this research. 


\section{DISCUSSIONS AND CONCLUSIONS}

Attachment as we have apprehended it according to its two components; Friendship and dependence must in our view have a positive impact on behavioural and attitudinal fidelity. The results we have achieved are not in perfect harmony with what we have been waiting for. Only addictive attachment had a positive and significant impact on behavioural and attitudinal fidelity. We need to focus more on the notion of addiction in the context of brand attachment in order to better understand how this component of attachment not only achieves a loyal consumer behaviour expressed by re-buying Brand, but also allows the consumer to develop a favourable attitude towards the latter. As for the second component of the attachment that we have studied and which concerns the attachment of friendship, the two hypotheses we have put forward were rejected. The attachment of friendship does not allow to deduce a positive link with the behavioural and attitudinal fidelity, on the contrary the link between this attachment of friendship and the two components of the fidelity is negative but remains nonetheless significant. Should we then question the mechanism by which these two components of attachment act and how the attachment of friendship has a contradictory and unpredictable impact on fidelity?

We were also interested in analysing the moderating role of nostalgic connections in the link between attachment on the one hand of dependence and the two components of fidelity, the same analysis was redone to concern this time the moderating link between The attachment of friendship and fidelity with its two components. The results we obtained oblige us to reject the two hypotheses according to which the nostalgic connections play a moderating role between on the one hand the attachment of friendship and the attachment of dependence and on the other hand the fidelity with its behavioural component and attitudinal. Although our conclusion about the rejection of the moderator relationship concerns both types of attachment, it is also important to point out that the moderating link in the relationship between dependency attachment and the two types of fidelity is admittedly negative but is nonetheless significant, contrary to the moderating link in the relationship between the attachment of friendship and fidelity. If nostalgic connections do not have a moderating effect, their intervention in the relationship between attachment and fidelity cannot be ruled out, the effect of nostalgia can pass indirectly and completely through the concept of attachment Bellaaj and Akrout, 2008). The nostalgic connections as we have treated them do not allow us to identify their usefulness for the respondents; the latter are sensitive at different levels to nostalgia and this according to their generational belonging or the utility they seek to satisfy The rejected moderator link may also be caused by an inconsistency between the desire to recall a period of life or a person with the (happy or unhappy) quality of the period in question, or because it is no longer possible to relive The quietude of childhood or adolescence, or the loss of a person who reminds us of a particular event. We cannot confirm this proposal on the basis of our results, but this is one of the future paths of our research, together with other clarifications that we need to bring to our sample, particularly in terms of generations, here a diversity of generations (Generation after the war, Baby Boomers, Generation $\mathrm{X}$ and $\mathrm{Y}$ ) as well as considering the classifications of profits sought by the consumption of nostalgic brands to which the consumer can demonstrate attachment (functional benefits, experiential Time profits) (Kessous and Roux, 2014). It will also be interesting to deal with the relationship of attachment by taking into account the nostalgic connections (whose place as antecedent, moderator or mediator is to be tested) in particular situations in order to better understand the strength of the bond of attachment with The intervention of nostalgia to be able to maintain a relationship of fidelity between the brand and the consumer.

Table 5: Validation of research hypotheses

\begin{tabular}{|c|c|c|c|c|}
\hline Hypothesis & $\begin{array}{l}\text { Expected } \\
\text { sign }\end{array}$ & Signe of the relation & $\begin{array}{l}\text { Significance } \\
\text { of links }\end{array}$ & Decision \\
\hline $\begin{array}{l}\mathrm{H} 1_{\mathrm{a}} \text {.Adductiveattachment } \\
\rightarrow \text { Behavioural loyalty }\end{array}$ & Positive & Positive & Significant & Accepted \\
\hline $\begin{array}{lll}\mathrm{H} 1_{\mathrm{b}} \cdot \quad \text { Adductive } & \text { attachment } \rightarrow \\
\text { attitudinal loyalty } & \\
\end{array}$ & Positive & Positive & Significant & Accepted \\
\hline $\begin{array}{l}\mathrm{H} 2_{\mathrm{a}} \cdot \begin{array}{l}\text { Friendship } \\
\text { attachment } \rightarrow \text { Behavioural loyalty }\end{array} \\
\end{array}$ & Positive & Negative & Significant & Rejected \\
\hline $\begin{array}{l}\mathrm{H} 2_{\mathrm{b}} \cdot \\
\text { attachment } \quad \rightarrow \text { attitudinal loyalty }\end{array}$ & Positive & Negative & Significant & Rejected \\
\hline $\begin{array}{l}\mathrm{H} 3_{\mathrm{a} \cdot} \\
\text { connections } \rightarrow \text { (Adductive } \\
\text { attachment } \rightarrow \text { behavioural loyalty) }\end{array}$ & Positive & Negative & Significant & Rejected \\
\hline $\begin{array}{l}\mathrm{H} 3_{\mathrm{b}} \cdot \quad \text { Nostalgic } \quad \text { connections } \\
\rightarrow(\text { AdductiveAttachment } \rightarrow \text { ) }\end{array}$ & Positive & Negative & Significant & \\
\hline $\begin{array}{l}\mathrm{H} 4_{\mathrm{a}} \\
\text { connections } \rightarrow \text { (Friendship } \\
\text { attachment } \rightarrow \text { behavioural loyalty) }\end{array}$ & Positive & Negative & Unsignificant & \\
\hline H4 ${ }_{b} \quad$ Nostalgic $\quad$ connections & Positive & Negative & Unsignificant & \\
\hline
\end{tabular}




\begin{tabular}{|l|l|l|l|l|}
\hline $\begin{array}{l}\rightarrow \text { (Friendship attachment } \rightarrow \\
\text { attitudinal loyalty ) }\end{array}$ & $\rightarrow$ & & & \\
\hline
\end{tabular}

Source: Authors elaboration

\section{REFERENCES}

[1] Baker S.M. et Kennedy P. F. (1994), Death By Nostalgia: A Diagnostic of Context-Specific-Cases, Advances in Consumer Research, 21, ed. C. Allen et D. Roedder- John, Provo, Utah, Association for Consumer Research, 169-174

[2] Baldinger A.L. etRubinson J. (1996), Brand Loyalty: the Link between Attitude and Behavior, Journal of Advertising Research, 36, 6, 22-34.

[3] Ball A.D et Tasaki L.H, 1992, The role and measurment of attachment in Consumer Behavior, Journal of consumer Psychology, 1, 2,155-172.

[4] Baudrillard, Richins1994

[5] Belaïd et Lacoeuilhe, 2005, « une validation interculturelle de l'échelle de l'attachement à la marque », Cahier de recherche, Institut de Recherche et de Gestion, Université Paris XI.

[6] Belaïd S. etLacoeuilhe J. (2005), «Une validation interculturelle de l'échelled'attachement à la marque », Cahier de recherche, Institut de RechercheenGestion, Université Paris XII.

[7] Belk R.W. (1988), Possessions and the Extended Self, Journal of Consumer Research, 15, 2, 139-168.

[8] Belk R.W. (1990), " The role of possessions in constructing and maintaining a sense of the past », Advances in Consumer Research, 17, 669-676.

[9] Bellaaj et Akrout, 2008, « Nostalgie et fidélité du consommateur: le rôlemédiateur de l'attachement à la marque ».

[10] Berscheid E. et Walster E.H. (1978), Interpersonal Attraction, Reading, MA: Addison-Wesley.

[11] Cristau C. (2001), « Définition, mesure et modélisation de l'attachement à une marque avec deuxcomposantes: La dépendance et l'amitié vis-à-vis d'une marque », Working Paper n 591, CEROG, IAE d'aix-en-Provence, Université Aix-Marseille III, 1-32.

[12] Csikszentmihalyi M. etRochberg-Halton E. (1981), The Meanings of Things: Domestic Symbols and the Self, Cambridge University Press.

[13] Davis F. (1979), Yearning for Yesterday: Sociology of Nostalgia, New York, the Free Press.

[14] Day G.S. (1969), A Two Dimensional Concept of Brand Loyalty, Journal of Advertising Research, 9, 3, 67-76.

[15] Day G.S. (1980), « Research perspectives on consumer complaint behaviour », Theoretical Developments In Marketing, Eds. Lamb et Dunne, Chicago, Ama, 211-215.

[16] Divard R. et Robert- Demontrond P. (1997), « La nostalgie: un thèmerécentdans la recherche marketing », Recherche et Applications en Marketing, 12, 4, 41-61.

[17] Feldwick P. (1996), What is Brand Equity Anyway, and how do you Measure it?, Journal of the Market Research Society, 38, 2, 85-104.

[18] Fournier S. (1994), «A Consumer Brand Relationship: Framework for strategic brand management », Dissertation at the University of Florida.

[19] Gouteron, 2008. L'impact de la personnalité de la marquesur la relation à la marque dans le domaine de la téléphonie mobile. La revue des sciences de gestion : Direction et Gestion.

[20] Heilbrunn B. (1996), Consumer Values and Brand Attachment, 49 thEsomar Congress, Changing Business Dynamics, 122-137.

[21] Heilbrunn B. (1996), Les Facteursd'Attachement du Consommateur à la Marque, Présentation au Séminaire de Recherche du DMSP, 18 janvier.

[22] Heilbrunn B. (2001), "Les facteursd'attachement du consommateur à la marque ", Thèse pour l'obtention du titre de docteuren Sciences de Gestion, Université Paris-Dauphine.

[23] Holbrook M. B. et Schindler R. M. (2003), « Nostalgic Bonding: Exploring the role of nostalgia in the consumption experience », Journal of Consumer Behaviour, 3, 2, 107-127.

[24] Holbrook M.B. et Schindler R.M. (1989), « Some Exploratoring Findings on the development of the musical tastes », Journal of Consumer Research, 16, 119-124.

[25] Holbrook M.B. et Schindler R.M. (1991), « Echoes of the Dear Departed Past: Some work in Progress On Nostalgia », Advances in Consumer Research, 18, 330-333.

[26] Holbrook M.B. et Schindler R.M. (1996), « Market Segmentation Based on Age and Attitude Toward the Past: Concepts, Methods, and Findings Concerning Nostalgic Influences on Consumer Tastes », Journal of Business Research, 37, 27-39.

[27] Kant E. (1798), Anthropologie du point de vuepragmatique, Euvresphilosophiques, Tome III, Paris, Ed. Gallimard, La Pléiade, 1986.

[28] Keller K.L. (1993), Conceptualizing, Measuring and Managing Customer-Based Brand Equity, Journal of Marketing, 57, 1, 1-22. 
[29] Kessous A. et Roux E. (2006), « La nostalgiecommeantécédent de l'attachement à la marque », 5ème Congrèssur les Tendances du Marketing en Europe, Venise, 20-21 Janvier.

[30] Kleines S. et al. (1995), How is a Possession me or not me? Characterizing Types and an Antecedent of Material Attachment, Journal of Consumer Research, 22, 3, 327-43.

[31] Lacoeuilhe J. (1997), « Le rôle du concept d'attachementdans la formation du comportement de fidélité », Revue Française du Marketing, 165, 5, 29-42.

[32] Lacoeuilhe J. (1999), " Proposition d'uneéchelle de mesure de l'attachement à la marque », Actes du Congrès International de l'AFM, Strasbourg, 1-13.

[33] Lacoeuilhe J. (2000), « L'attachement à la marque: proposition d'uneéchelle de mesure », Recherche et Applications en Marketing, 15, 4, 61-77.

[34] Maissonneuve J. (1966), Psychosociologie des Affinités, Paris, PUF.

[35] McQueen J et al.,( 1993), Decomposing a Brad's Consumer Franchise Into Buyer Types, Brand Equity and Advertising, éd.D.AAaker et ABiel, Hillsdale,NJ,Lawrence Erlbaum

[36] Onkvisitet Shaw (1987), Self-Concept and Image Congruence, Journal of Consumer Marketing, 4, 13-23.

[37] Park C.W. et Srinivasan V. (1994), A Survey-Based Method for Measuring and Understanding Brand Equity and its Extendibility, Journal of Marketing Research, 31, 2, 271-288.

[38] Richins et Dawson, 1992, « Measuring materied values » Advances in Consumer Reasearch, 17,169-175

[39] Richins M.L.(1994)Valuing Things: the public and Private Meanings of the self, Journal of Consumer Research,21,3,504-521.

[40] Sheth J. N. etParvatiyar A. (2000), Handbook of Relationship Marketing, Sage Publications. Singh J. (1990), «A typology of consumer dissatisfaction response styles », Journal of Retailing, Vol. 66. 